\section{OPEN JOURNAL SYSTEMS}

ISSN:2237-2202
Available on line at Directory of Open Access Journals

Journal of Hyperspectral Remote Sensing v.7, n.7 (2017) 389-398

www.periodicos.ufpe.br/revistas/jhrs
Journal of Hyperspectral Remote Sensing

\title{
Influence of the use and the land cover of the catchment in the water quality of the semiarid tropical reservoirs
}

\author{
Hérika Cavalcante , Patrícia S. Cruz ${ }^{*}$, Leandro G. Viana ${ }^{* *}$, Daniely de L. Silva ${ }^{* * *}$, José E. de L. Barbosa ${ }^{* * * *}$ \\ "Doctor Student in in Post-Graduate Program in Environmental Engineering, State University of Paraíba - UEPB, E-mail: \\ herikacavalcante@yahoo.com (Corresponding author); patriciacruz_biologa@ hotmail.com. \\ *** Master in Environmental Science and Technology, UEPB, e-mail: leandrogomesbiologo@ gmail.com. \\ ${ }^{* * * *}$ Master Student in Post-Graduate Program in Environmental Science and Technology, UEPB. \\ ${ }^{* * * *}$ Associate Professor in Department of Biology in UEPB, E-mail: ethambarbosa @ hotmail.com.
}

Received 13 June 2017; accepted 30 October 2017

\begin{abstract}
The aim of this study was to evaluate some parameters of water quality of semiarid reservoirs under different uses and occupation of the catchment's soil. For this, the reservoirs Acauã and Boqueirão, belonging to the Paraíba do Norte river watershed and Middle and Upper course sub catchments, respectively, were studied. For this, water samples were collected in August, September and October 2016. From these samples, total and dissolved phosphorus, nitrate, nitrite, ammonia, chlorophyll, dissolved and suspended solids were analyzed. In addition, images of the Landsat 8 satellite were acquired for the calculation of the Normalized Difference Vegetation Index (NDVI), and for the supervised classification of the use and occupation of the sub catchments. Thus, it was observed that, in general, the Acauã reservoir presented values of phosphorus and nitrogen and solids larger than the Boqueirão reservoir, due to the greater urban area, even though it had a smaller total area of the basin. Both reservoirs presented low vegetation rates and high areas of sparse vegetation and exposed soil, increasing the propensity to soil erosion and the transport of nutrients from the basin to the reservoirs, making water quality worse or impossible.
\end{abstract}

Keywords: Anthropogenic activities, Eutrophication, Vegetation Index.

\section{Introduction}

Anthropic action can cause great changes in the natural environment, depending on the activity carried out in the locality. It is common to correlate degree of industrialization of a place with the amount of pollutant loads in aquatic environments, mainly lotic, like lakes and weirs. However, the simple presence of urbanization and agricultural activities can greatly affect the water quality of water bodies, behaving as major pollution generators (Schneider et al., 2011).

Urban sprawl can have major consequences on the environment without an environmental vision, such as the deterioration of the quality and quantity of water sources, generating a qualitative scarcity (Prat and Munné, 2000). Among the damages in the water quality, is it possible to highlight your high enrichment by nutrients, mainly phosphorus $(\mathrm{P})$ and nitrogen $(\mathrm{N})$, process entitled eutrophication.

The eutrophication is a natural process that can occur in water bodies after centuries or decades of natural nutrient supply. However, when associated with anthropic activities, the phenomenon becomes more accelerated, occurring in a shorter period of time such as decades or years, and may be called artificial or cultural eutrophication, which is one of the most common water quality problems of the present time (Smith and Schindler, 2009). Increased nutrient availability leads to phytoplankton community growth and the incidence of potentially toxic cyanobacteria, causing processes of organic matter decomposition and significant depletion of dissolved oxygen, which can lead to the loss of aerobic aquatic communities and generate losses in the scenic quality of the environment (Carpenter et al., 1998).

The difficulty of identifying diffuse sources makes it important to monitor the landscape, since the classification of the use and occupation of the soil of a river basin is an efficient tool in the verification of diffuse sources of pollution to the aquatic body. The evaluation of the information obtained through remote sensing has generated satisfactory results, both for the accuracy of the results, for the agility in obtaining the 
data and the lower cost compared to traditional methods (Sá et al., 2008).

Modifications in use and occupation, as the land cover of watersheds can contribute for rate variation of surface runoff, sediment transport and nutrient flow (Ismail and Najib, 2011), significantly altering the biological, physical and chemical processes of water bodies (Merten and Minella, 2002).

In this way, it is essential to investigate the activities developed in river basins, mainly from sources of human supply, so that it is possible to guarantee the environmental quality of soil and water (Li et al., 2015). Linked to this, semiarid regions may be quite susceptible to diffuse pollution of springs due to the peculiar characteristics of the region, such as shallow soils with little vegetation cover (Oyama and Nobre, 2004), rainfall that can occur intensively in a few days of the year, and may promote greater erosion and increase of the soil nutrient potential of the soil from the basin to the water (Haregeweyn et al., 2008).

The aim of this study was to evaluate some water quality parameters of reservoirs in the Brazilian semiarid region under different uses and occupation of the soil of the watersheds.

\section{Materials and methods}

2.1 Study Area
The study was conducted in two reservoirs of the tropical semiarid region: Argemiro Figueiredo reservoir, better known as Acauã; and Epitácio Pessoa reservoir, better known as Boqueirão. Both reservoirs belong to the Paraíba river basin (Figure 1).

The Paraíba river catchment is located in the Paraíba state and has an area of approximately 20070 $\mathrm{km}^{2}$, covering about $35 \%$ of the Paraíba territory. The catchment covers 86 counties; therefore, it is the second largest basin in the state, behind only the Piranhas river catchment (AESA, 2017). The area surrounding the basin has a diversity of climates and physical characteristics, as well as a great geographic extension, divided into four regions: upper course, Middle course and lower course of the Paraíba River in addition to the Taperoá Sub catchment. The Acauã reservoir is embedded in the Middle Sub catchment course, while Boqueirão is located in the Upper Sub catchment course (Figure 1).

Both reservoirs have as their uses the human supply (priority use), being responsible for supplying more than 20 municipalities in the Cariri region of Paraíba, animal watering and irrigation (AESA, 2017).

The catchment comprise several types of soils, however, the greatest predominance is Neossolo Litólico and Luvissolo Crômico, both young, underdeveloped and shallow soils, typical of the Brazilian semiarid region (EMBRAPA, 2017).

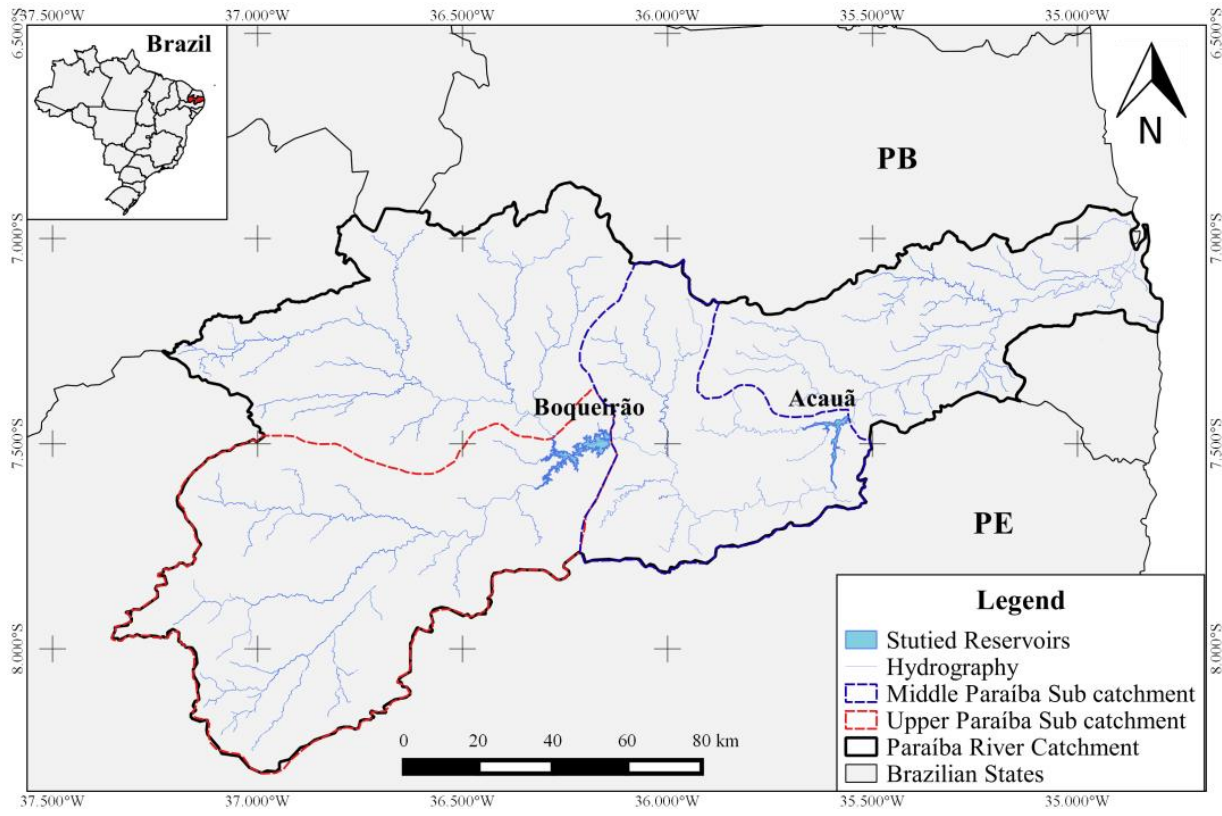

Figure 1- Location of the catchments of the Acauã and Boqueirão Reservoirs. Geographical coordinate system and reference system SIRGAS 2000. 
From 2012 until the end of the work (September 2017), the region of the basin of the reservoirs is in a prolonged drought period, which caused a great decrease in the levels of the reservoirs. The Acauã reservoir has a maximum capacity of $253,000,000 \mathrm{~m}^{3}$, in August 2016 (water collection period of this study) it had only wax of $11 \%$ of the total volume stored (AESA, 2017). The Boqueirão reservoir has a maximum storage capacity of $418,088,514 \mathrm{~m}^{3}$, being in August 2016 with approximately $8 \%$ of its total volume (AESA, 2017).

\subsection{Vegetation Index and Classification of land use and cover}

Orbital images captured by the Operational Land Imager (OLI), installed on the Landsat- 8 satellite and made available by the United States Geological Survey (USGS, 2017) were used to perform this work. Three images were used, two captured on November 14, 2015 and the third on November 7, 2015. The criterion for choosing such images took into account proximity to the date of water collection and a cloud percentage of less than $20 \%$. Bands 4, 3 and 2 were considered to compose the visualization in natural color and to obtain vegetation indices bands 4 and 5 .

The supervised classification of the use and occupation of the soil of the catchment of the reservoirs (Figure 1) was done through the Semi-automatic Classification Plugin (SPC) of the free access software QGIS. The classes were divided into: 1 - Water; 2 Vegetation of the Flood area, which corresponds to the vegetation that grew in the channel of the rivers or the banks of the reservoirs, since the period of drought reduced considerably the water levels; 3 - Sparse vegetation, which includes some plantations, pasture areas and even the natural vegetation characteristic of the semiarid region in dry periods; 4 - Dense vegetation, which corresponds to the natural vegetation of the region that are in good state of preservation; 5 Exposed soil e; 6 - Urban, which corresponds to the clusters that the satellite can identify, since there are also other small settlements or dwellings that are imperceptible to the satellite. Note that in the classes there is no agriculture and livestock directly, however these are implicit mainly in class 3 (sparse vegetation).

In order to aid in the classification, we performed the QGIS processing of the index that represents the soil cover, the Normalized Difference Vegetation Index (NDVI) calculated by equation 1 . The NDVI was initially proposed by Rouse et al. (1973) and is used mainly in environmental research, since it allows to make analyzes on the vegetation cover of a certain region in different scales. It is obtained by the ratio between the difference of the near infrared reflectance (NIR) and the red reflectance (R), divided, respectively, by the sum of the same. In the case of the Landsat- 8 satellite, the NIR and R bands are, respectively, 5 and 4 . The index can vary from -1 to +1 , with higher values with higher vegetation intensity.

$$
\mathrm{NDVI}=\frac{(\mathrm{NIR}-\mathrm{R})}{(\mathrm{NIR}+\mathrm{R})}
$$

\subsection{Sampling and analysis of water}

Surface water samples were collected for analysis of nutrients by means of a van dorn bottle at a point near the uptake in both reservoirs. The samples were conditioned in polyethylene bottles and filtered in a $\mathrm{GF} / \mathrm{C}$ glass vibration filter for the determination of dissolved nutrients. The collections were carried out in three months: August, September and October of the year 2016.

The concentrations of ammonia $(\mathrm{NH} 4+)$, nitrate (NO3-), nitrite (NO2-), total phosphorus (PT), soluble reactive phosphorus (FRS), chlorophyll a (Chl-a), total dissolved solids (SST) were determined according to standardized methodologies described in Standard Methods for the Examination of Water and Waste Water (APHA, 2012).

\section{Results and discussion}

NDVI is known to be an indicator of photosynthetic activity, with good efficiency for analysis in drier climates (Liesenberg et al., 2007). In general, low vegetation rates were observed in both the Acauã catchment (Figure 2) and the Boqueirão catchment (Figure 3). A minimum value of 0.09 and a maximum value of 0.27 was detected. Espig et al. (2008) studied the seasonal variations in the caatinga vegetation in six areas of the northeastern semiarid region using MODIS data, estimating NDVI minimum values in area $1,0.22$; area 20.10 ; area 30.22 ; area 4 0.09 ; area 5.11 and area 0.21 ; already the maxima were estimated in area 10.87 ; area 20.78 ; area 30.63 ; area 4 0.96; area 50.76 and area 60.66 . The values found in this study show similarity with the values of Espig et al. (2008) only for the minimum values; however the maximum values found are much lower. This may mean that the minimum amount of vegetation is within the standards of the region, however due to the long period of drought in the region studied there was considerable decrease of dense vegetation, so low maximum values. 
The low intensity of vegetation in the watershed is a cause for concern, and even more so when this fact is also observed in the vicinity of the reservoirs, i.e. in the riparian zone (Figures 2 and $3 \mathrm{~b}$ ), where soil nutrient leaching and their own loss to the water body has even more influence. Therefore, the preservation of the riparian strip is of extreme importance because it avoids the erosion of adjacent soils, preventing or attenuating sedimentation and sedimentation of the bed (Coelho et al., 2011). In the Boqueirão reservoir there is a greater predominance of pixels in the class 0.26 around the water mirror, which could indicate the presence of the riparian forest. However, in visits to the site it is possible to perceive that the region is part of the flood area of the reservoir, which is very low in volume. Therefore, the moisture and nutrient content of the flood region is conducive to the development of plants, therefore, local people grow plants for feeding in this flood region that is on the banks of the reservoir, which explains the high vegetation index obtained. (a)

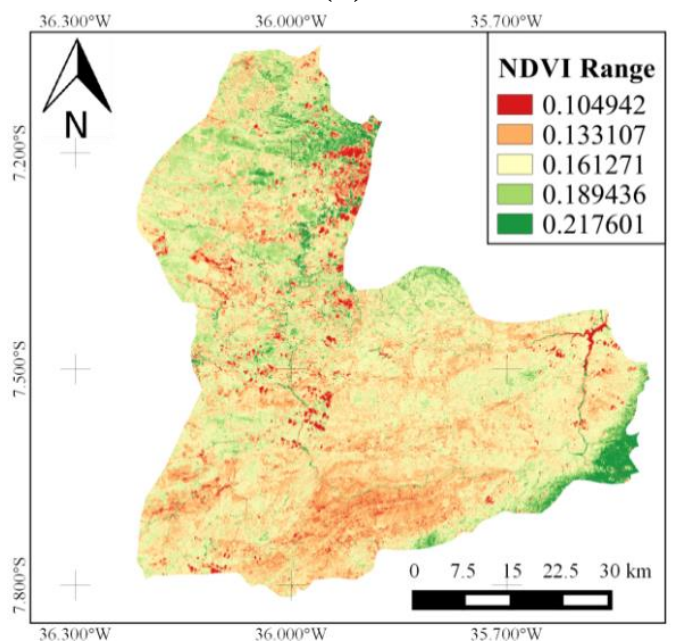

(b)

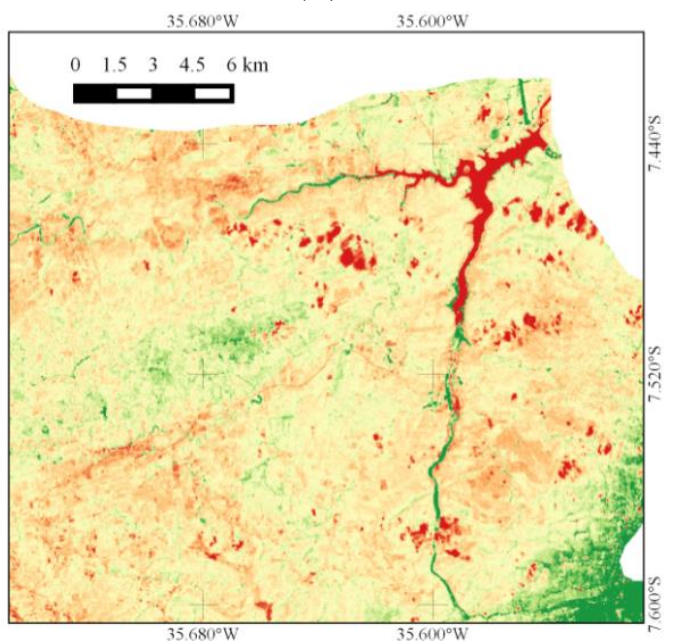

Figure 2 - NDVI for the Paraíba Middle Sub catchment, where the Acauã Reservoir is located: (a) Sub Catchment overview and (b) Approach to the Acauã Reservoir. NDVI obtained from two images of Landsat 8 of days November 07 and 14, 2015, in the coordinate system UTM, zones 24 S and 25 S, SIRGAS 2000 reference system.

(a)

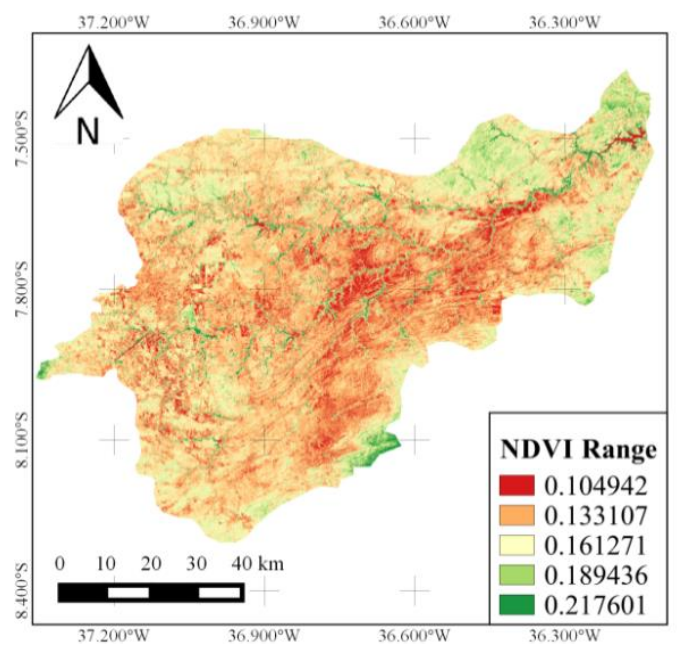

(b)

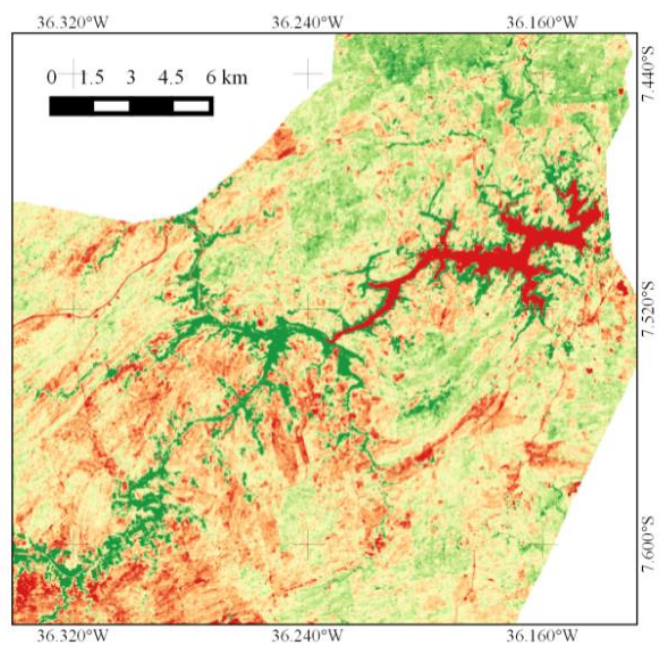

Figure 3 - NDVI for the Paraíba Upper Sub catchmanet, where the Boqueirão Reservoir is located: (a) Sub catchment overview and (b) Approach to the Acauã Reservoir. NDVI obtained from image of Landsat 8 of day November 14, 2015, in the coordinate system UTM, zone 25 S, SIRGAS 2000 reference system. 
The supervised classifications of the satellite images allowed the identification of 6 classes of land use and cover/occupation: water, flood vegetation, sparse vegetation, dense vegetation, exposed and urban soil. Agriculture and livestock were not identified directly, however, are encompassed in the sparse vegetation portion. While dense vegetation encompasses native forest.

Figure 4 (a) shows the classification performed in the middle Paraíba sub catchment, where the Acauã reservoir is inserted. And Table 1 shows the areas of each class, as well as the percentage in relation to the total area of the basin, which was calculated in approximately $3,000.00 \mathrm{~km}^{2}$. According to the classification, the largest percentage of occupied area in the basin was sparse vegetation (38\%), followed by exposed soil (36\%) and dense vegetation (21\%).
Similar to the average Middle sub catchment, Figure 4 (b) and Table 1 show the data for the upper sub catchment. The classification as well as the areas of each class of land use are shown, as well as the percentage in relation to the total area of the catchment, which was calculated in approximately $5,600.00 \mathrm{~km}^{2}$. According to the classification, the predominance of the classes was similar to the Middle sub catchment, being the largest percentage of area occupied in the basin of sparse vegetation (43.85\%), followed by exposed soil (38.26\%) and dense vegetation (16.68\%). However, as the area of the Boqueirão catchment is larger, the delimitation of the predominant classes was greater, except for the urban class, which in Acauã presented a larger area, due to the higher urbanization index of the middle sub catchment in relation to the upper sub catchment. (a)

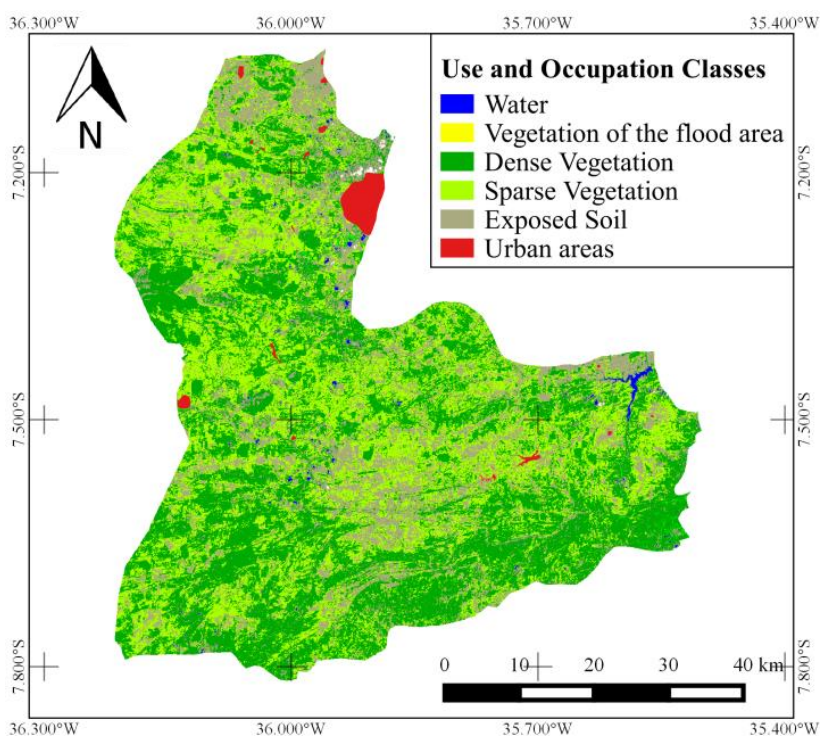

(b)

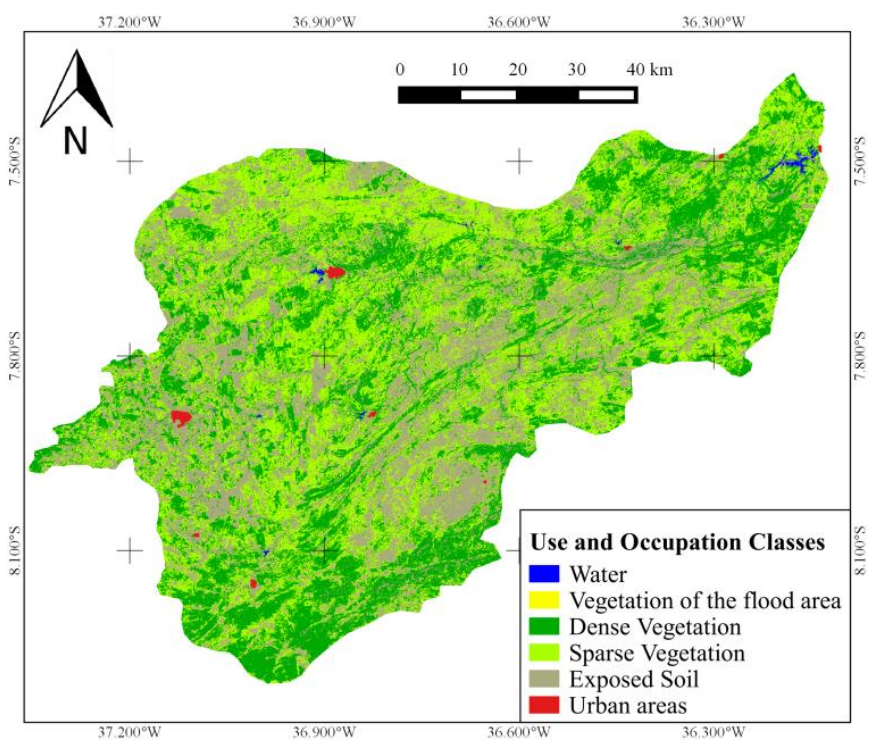

Figure 4 - Classification of land use and occupation of the (a) Middle Sub catchment, belonging to the Acauã reservoir and (b) Upper Sub catchment, belonging to the Boqeuirão reservoir. Classification obtained from three images of Landsat 8 of days November 07 and 14, 2015, in the coordinate system UTM, zones 24 S and 25 S, SIRGAS 2000 reference system.

As previously mentioned, sparse vegetation includes places where there is little native vegetation, which has lost due to dry season, livestock or pasture areas or some types of plantations. The agriculture class was not taken into account, because the reflectance presented different patterns, probably according to each culture, sometimes confused with dense or sparse vegetation. However, observing images of the site through Google Earth, which has a better spatial resolution, it was possible to verify that the class sparse vegetation was predominantly pasture.

Livestock farming in the semi-arid region is generally practiced extensively in the open field, so that the herds have access to land that has sparse natural vegetation, which enables both locomotion and feeding. In addition, it is common practice to burn in areas of arboreal or shrubby caatinga by the breeders, in order to facilitate the budding of the pasture soon after the rainy season (Medeiros, 2016)Table 1 - Areas and percentages of each class of the catchment studied. 


\begin{tabular}{|c|c|c|c|c|}
\hline \multirow[t]{2}{*}{ CLASSE } & \multicolumn{2}{|c|}{$\begin{array}{l}\text { Middle Sub } \\
\text { catchment } \\
(\mathbf{A C A U \tilde { A } )}\end{array}$} & \multicolumn{2}{|c|}{$\begin{array}{c}\text { Upper Sub } \\
\text { catchment } \\
\text { (BOQUEIRÃO) }\end{array}$} \\
\hline & $\mathbf{k m}^{2}$ & $\%$ & $\mathbf{k m}^{2}$ & $\%$ \\
\hline Water & 3,54 & 0,12 & 2,19 & 0,04 \\
\hline $\begin{array}{l}\text { Flood } \\
\text { Vegetation }\end{array}$ & 15,94 & 0,53 & 15,59 & 0,28 \\
\hline $\begin{array}{l}\text { Dense } \\
\text { vegetation }\end{array}$ & 657,31 & 21,85 & 944,56 & 16,68 \\
\hline $\begin{array}{l}\text { Sparse } \\
\text { vegetation }\end{array}$ & 1164,86 & 38,72 & 2482,85 & 43,85 \\
\hline $\begin{array}{l}\text { Exposed } \\
\text { soil }\end{array}$ & 1106,01 & 36,77 & 2166,28 & 38,26 \\
\hline Urban & 60,54 & 2,01 & 50,32 & 0,89 \\
\hline TOTAL & 3008,2 & 100,00 & 5662 & 100,00 \\
\hline
\end{tabular}

The intense trampling of the animals as well as their food degrades the native forest, which can lead to their disappearance, leaving the soil completely exposed. Therefore, we can still consider that livestock farming is also included in the exposed soil class. Lack of management in semi-arid environments, coupled with large anthropogenic impacts and the fragility of the region contribute to soil degradation (Pereira and Dantas Neto, 2014). However, the fact that soil is an open system causes the consequences of use and occupation not to be restricted to the soil, but also to an intense effect on water.

The class Vegetation flood area, although little expressive in terms of amount of area, can be a worrisome area, as they correspond to the region of the basin of the reservoir that is exposed in the dry period. The problem in these areas is that they are often harvested for planting, especially crops that are used for animal feed. This is done because the area remains damp during the dry season, reducing the need for irrigation, and the nutrients that may exist in the exposed sediment are still used. Even without the use of fertilizers in this region, it is not advisable to plant in the floodplain areas, nor in the Permanent Protection Area (PPA) of the reservoirs, which corresponds to 100 $\mathrm{m}$ distance from the shore when the water table is in its maximum quota When fertilizers are added to this planting the situation is even more serious, setting itself up as a certain source of nutrients for water.

Figure 5 shows some water quality parameters of the Acauã and Boqueirão reservoirs that were analyzed during a study period just prior to the dates of the satellite images used for the classification of the use and occupation. Among the analyzed parameters are mainly phosphorus (total and dissolved) and nitrogen (in ammonia, nitrate and nitrite), which may be present in large quantities in the soil, due to the activities developed in it (such as agriculture and livestock), being able to be carried to the water bodies, or by leaching to soil losses by erosion. Once in the water bodies, the excess nutrients can trigger a process called eutrophication. This process can lead to excessive growth of algal blooms and aquatic plants (Huang et al., 2017), reduces biodiversity, can lead to fish mortality due to the occurrence of anoxic conditions. Another major problem related to eutrophication is the proliferation of cyanobacteria that pose risks to public health (Vidal and Capelo Neto, 2014). In general, the enrichment of water bodies by nutrients seriously damages water quality.

Since when eutrophication was first noticed in 1931 by Naumann, it was attributed to nitrogen (N) and phosphorus (P) (Moss et al., 2013), both considered as limiting nutrients for phytoplanktonic growth (Schindler et al., 1973). Nesse estudo, as quantidades de nitrogênio foram apresentadas nas formas nitrato, nitrito e amôna, Figura 5 (a). The nitrate values were around $25 \mu \mathrm{g} . \mathrm{L}^{-1}$ for Acauã and $30 \mu \mathrm{g} . \mathrm{L}^{-1}$ for Boqueirão, while the nitrite values were below $10 \mu \mathrm{g} . \mathrm{L}$ ${ }^{1}$ in both reservoirs, however, ammonia presented mean values of $23 \mu \mathrm{g} . \mathrm{L}^{-1}$ for Acauã and, $15 \mu \mathrm{g} . \mathrm{L}^{-1}$ for Boqueirão. Bacteria are responsible for the transformation of ammonia into nitrite and then into nitrate (Barbieri et al., 2014). The greater presence of ammonia in Acauã may suggest that there is greater input of organic material from the river basin. The nitrate values were around $25 \mu \mathrm{g} . \mathrm{L}^{-1}$ for Acauã and 30 $\mu \mathrm{g} . \mathrm{L}^{-1}$ for Boqueirão, while the nitrite values were below $10 \mu \mathrm{g} . \mathrm{L}^{-1}$ in both reservoirs, however, ammonia presented mean values of $23 \mu \mathrm{g} . \mathrm{L}^{-1}$ for Acauã and 15 $\mu \mathrm{g} . \mathrm{L}^{-1}$ for Boqueirão. Bacteria are responsible for the transformation of ammonia into nitrite and then into nitrate.

Phosphorus, Figure 5 (b), may also act as a limiting factor on primary production in aquatic ecosystems and may lead to eutrophication (Lamparelli, 2004). A maximum amount of $50 \mu \mathrm{g} . \mathrm{L}^{-1}$ of total phosphorus in the aquatic environments of the semiarid so as not to be considered eutrophic (Thornton and Rast, 1993). During the collection period, the Acauã reservoir had mean values of total phosphorus (PT) around $150 \mu \mathrm{g} . \mathrm{L}^{-1}$, while the Boqueirão reservoir presented values around $125 \mu \mathrm{g} . \mathrm{L}^{-1}$. Thus, both reservoirs can be considered eutrophic. However, the values of soluble reactive phosphorus are low for both reservoirs and did not present significant differences. 
Probably, this low amount of soluble reactive phosphorus is due to the rapid capture by phytoplankton or aquatic plants. The presence of submerged macrophytes was evidenced in several periods in the Boqueirão reservoir and also of cyanobacteria in both reservoirs, especially the

(a)

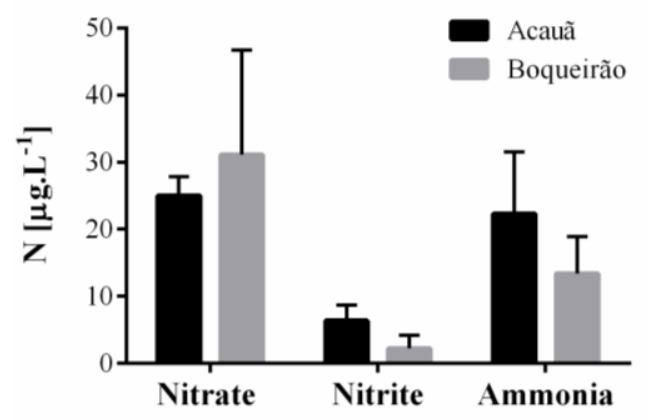

(c)

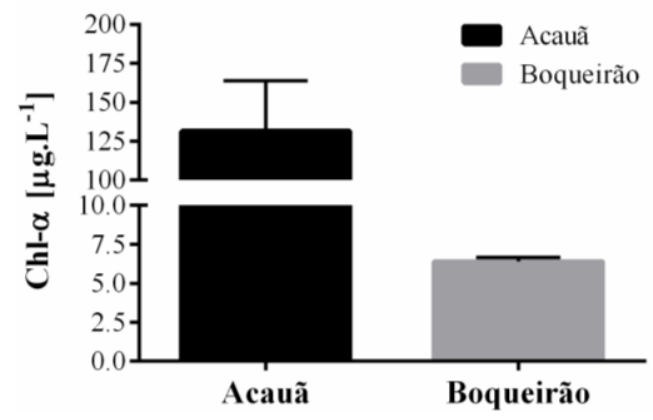

reservoir that does not present macrophytes, the Acauã reservoir (Monteiro, 2016). Biomasses of cyanobacteria and macrophytes tend to rapidly capture the soluble reactive phosphorus present in the water in the reservoir, so that the amounts detected in the analyzes are generally low.

(b)

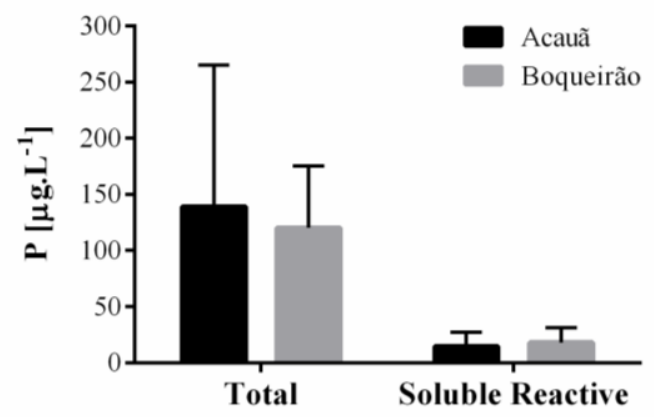

(d)

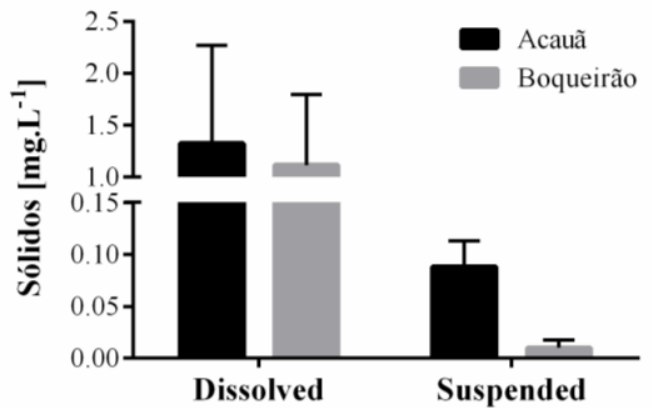

Figure 5 - Water quality parameters of the Acauã and Boqueirão reservoirs.

The chlorophyll, Figure 5 (c), was significantly higher in the Acauã reservoir, reaching mean values of $130 \mu \mathrm{g} . \mathrm{L}^{-1}$ while Boqueirão presented values below 10 $\mu \mathrm{g} . \mathrm{L}^{-1}$. This fact is related to phytoplanktonic and macrophyte quantities, as mentioned previously. Phytoplankton biomass decreases with increasing levels of submerged macrophytes (Sànchez et al., 2014). In a study of the Acauã and Boqueirão reservoirs, it was observed that increased coverage of aquatic plants reduced phytoplankton biomass through competition for nutrients (Monteiro, 2016). However, the contribution of nutrients can promote the development of both cyanobacterial or phytoplankton blooms in general and of macrophytes, not ruling out the influence of nutrient inputs from the high basin course in the Boqueirão reservoir only due to the lower content of chlorophyll and consequently phytoplanktonic.
The amount of solids, Figure 5 (d), was higher in the Acauã reservoir, with significant differences for the suspended solids. The concentration of suspended solids directly influences the turbidity, since it hinders the penetration of light into the water (Chagas, 2015). The main sources of turbidity are clays, sand, organic matter, mineral material, debris and plankton (Chaves and Santos, 2009). These materials can come from erosive processes and aggregate products carried to the watercourses through the surface runoff (Chagas, 2015). The use and occupation can change the physical-chemical attributes of the soil (Pereira and Tomaz, 2015), increasing the nutrient content and the susceptibility to erosion (Ouyang et al., 2010). Erosive processes in turn may be the result of activities such as cattle raising, a fact already mentioned previously. The class of sparse vegetation and exposed soil, which encompass livestock activities, were high and 
predominant in both reservoirs, which influenced the high amounts of suspended solids in the reservoirs.

The relationship between land use and occupation and water quality is already well recognized in the literature, however, there are several factors that intervene in the process, and the dynamic characteristics of the environment make the determination of its modification difficult and elusive. Most of the studies in the area have been empirical, relating the type of use, coverage and management of the soil with water quality (Chaves and Santos, 2009; Roy et al., 2003). Most of these studies show a worsening of water quality such as increased land use and occupation (Chaves and Santos, 2009). This study corroborates with those previously mentioned.

In relation to the differences between the land uses of the basins of the reservoirs, it can be stated that, despite the smaller area of the middle basin, of the Acauã reservoir, it has a larger urban area, which can greatly influence the quality of the reservoir, not only by reducing dense vegetation rates, but also by allowing the clandestine supply of sewage, as is the case of Acauã, popularly known to withstand clandestine sewage loads. However, both basins obtained high values of sparse vegetation and exposed soil, which is worrying. This allows to indicate that the reservoirs studied are under strong impacts from diverse origins in their drainage basin, such as agricultural and goat rearing activities, which influence the quality of their waters. In addition, it is possible to affirm that livestock farming is a worrying activity, since it increases nutrient contents and can even intensify the erosive process of soils. On the other hand, the agriculture carried out in the basin without the use of fertilizers can help in the prevention of problems with the water quality of the reservoirs, as long as it is not practiced in the floodplain areas and in the APP, as in the region corresponding to the flood area class, in order to avoid the damage of the riparian zone and the contribution of allochthonous material.

\section{Conclusions}

In general, the Acauã reservoir presented values of phosphorus, nitrogen and solids larger than the Boqueirão reservoir, probably due to the greater urban area, even though it had a smaller total area of the basin. However, both reservoirs presented low vegetation indexes and high areas of sparse vegetation and exposed soil, which increases the propensity to soil erosion and the transport of nutrients from the soil of the basin to the reservoirs, making it worse or impossible to improve water quality. It was observed that livestock farming is one of the main activities impacting the soil and water of the region. Thus, more adequate management strategies that aim to reduce the inputs of phosphorus in the drainage basin, from point sources and diffuse, is fundamental to improve water quality.

\section{Acknowledgments}

The authors of this paper thank CAPES for the financial support and the Aquatic Ecology Laboratory for the logistic support of the collections and structure for the analyzes.

\section{References}

AESA. Agência Executiva de Gestão das Águas, 2017. Disponível: $\quad$ http://www.aesa.pb.gov.br/aesawebsite/. Acesso: 10 jul. 2017.

APHA. 2012. Standard Methods for the Examination of Water and Waste-water. 22.ed. APHA, AWWA and W.E.F., Washington.

Barbieri, E., Marques, H.L.A.de, Bondioli, A.C.V., Campolim, M.B., Ferrarini, A.T., 2014. Concentrações do nitrogênio amoniacal, nitrito e nitrato em áreas de engorda de ostras no município de Cananeia-SP. Mundo da Saude 38, 105-115.

Carpenter, S., Caraco, N., Correll, D.., Howarth, R.W., Sharpley, A.N., Smith, V.H., 1998. Nonpoint pollution of surface waters with phosphorus and nitrogen. Ecological Applications 8, 559-568.

Chagas, D.A., 2015. Relação entre concentração de sólidos suspensos e turbidez da água medida com sensor de retroespalhamento óptico. Universidade do Estadual do Sudoeste da Bahia.

Chaves, H.M.L., Santos, L.B.dos, 2009. Ocupação do solo, fragmentação da paisagem e qualidade da água em uma pequena bacia hidrográfia. Revista Brasileira de Engenharia Agrícola e Ambiental 13, 922-930.

Coelho, R.C.T.P., Buffon, I., Guerra, T., 2011. Influência do uso e ocupação do solo na qualidade da água: um método para avaliar a importância da zona ripária. Revista Ambiente \& Água 6, 104-117. doi:10.4136/1980-993X

EMBRAPA. Empresa Brasileira de Pesquisa Agropesuária, 2017.2 Disponível: https://www.embrapa.br/. Acesso: 10 jul. 2017.

Espig, S.A., Soares, J.V., Santos, J.R.dos., 2008. Variações sazonais do EVI e NDVI em áreas do semi-árido brasileiro. Seminário em Atualização em Senoriamento Remoto e Sistemas de Informações Geográficas Aplicados à Engenharia Florestal, Curitiba. 
Haregeweyn, N., Poesen, J., Deckers, J., Nyssen, J., Haile, M., Govers, G., Verstraeten, G., Moeyersons, J., 2008. Sediment-bound nutrient export from micro-dam catchments in northern Ethiopia. Land degradation \& development 19, 242-256.

Huang, J., Xu, C., Ridoutt, B.G., Wang, X., Ren, P., 2017. Nitrogen and phosphorus losses and eutrophication potential associated with fertilizer application to cropland in China. Journal of Cleaner Production 159 (2017) 171-179.

Ismail, W.R., Najib, S.A.M., 2011. Sediment and nutrient balance of Bukit Merah Reservoir , Perak (Malaysia). Lakes \& Reservoirs Research \& Management 16, 179-184.

Lamparelli, M.C., 2004. Graus de trofia em corpos d'água do estado de são paulo: avaliação dos métodos de monitoramento. Universidade de São Paulo.

Li, L., Liu, L., Wang, S., 2015. Spatial distribution of phosphorus fractions in sediment and the potential mobility of phosphorus in Dianchi Lake. Environmental Earth Sciences 74, 3721-3731.

Liesenberg, V., Jorge, F., Soares, L., 2007. Algumas fitofisionomias do Cerrado com índices de analysis of the seasonal dynamics and spectral separability of some savanna physiognomies with vegetation indices derived from Modis / terra and aqua. Revista Árvore 31, 295-305.

Medeiros, C.E.B.F. de S., 2016. Os impactos do uso e ocupação e evento de seca extrema na qualidade da água e do solo de um manancial na qualidade da água e do solo de um manancial. Universidade Federal do Rio Grande do Norte.

Merten, G.H., Minella, J.P., 2002. Qualidade da água em bacias hidrográficas rurais: um desafio atual para a sobrevivência futura. Revista Agroecologia e Desenvolvimento Rural Sustentável 3, 33-38.

Monteiro, F.M., 2016. Presença de macrófitas submersas altera a dinâmica do fitoplâncton em reservatórios do semiárido? Universidade Estadual da Paraíba.

Moss, B., Jeppesen, E., Søndergaard, M., Lauridsen, T.L., Liu, Z., 2013. Nitrogen , macrophytes , shallow lakes and nutrient limitation : resolution of a current controversy? Hydrobiologia 710, 3-21.

Ouyang, W., Skidmore, A.K., Toxopeus, A.G., Hao, F., 2010. Long-term vegetation landscape pattern with non-point source nutrient pollution in upper stream of Yellow River basin. Journal of Hydrology 389, 373-380.

Oyama, M.D., Nobre, C.A., 2004. Climatic Consequences of a Large-Scale Desertification in Northeast Brazil: A GCM Simulation Study.
Journal of Climate 17, 3203-3213.

Pereira, A.A., Tomaz, E.L., 2015. Atributos químicos do solo em áreas sob diferentes sistemas de uso e manejo no município de reserva - PR. Revista Caminhos de Geografia 16, 186-194.

Pereira, R.A., Dantas Neto, J., 2014. Efeito das atividades agropastoris sobre os atributos físicoquímicos de três classes de solos de uma bacia hidrográfica no Semiárido brasileiro. Boletim Goiano de Geografia 34, 169-188.

Prat, N., Munné, A., 2000. Water use and quality and stream flow in a Mediterranean stream. Water Research 34, 3876-3881.

Rouse, J.W., Haas, R.H., Schell, J.A., Deering, D.W., 1973. Monitoring vegetation systems in the Great Plains with ERTS. In: ETRS Symposium, Washington.

Roy, A.H., Rosemond, A.D., Paul, M.J., Leigh, D.S., Wallace, J.B., 2003. Stream macroinvertebrate response to catchment urbanisation (Georgia, USA). Freshwater Biology 48, 329-346.

Sá, I.I.S., Galvíncio, J.D., Moura, M.S.B. de, Sá, I.B. de, 2008. Uso do Índide de Vegetação da Diferença Normalizada (IVDN) para caracterização da cobertura vegetal da região do Araripe Pernambuco. Revista Brasileira de Geografia Física 1, 28-38.

Sànchez, M.L., Lagomarsino, L., Allende, L., Izaguirre, I., 2014. Changes in the phytoplankton structure in a Pampean shallow lake in the transition from a clear to a turbid regime. Hydrobiologia 1.

Schindler, D.W., Kling, H., Schmidt, R. V., Prokopowich, J., Frost, V.E., Reid, R.A., Capel, M., 1973. Eutrophication of Lake 227 by Arldition of Phosphate and Nitrate: the Second, Third, and Fourth Years of Enrichment, 1970, 1971, and 1972. Journal of the Fisheries Research Board of Canada 30, 1415-1440.

Schneider, R.M., Freire, R., Cossich, E.S., Soares, P.F., Freitas, F.H. de, Tavares, C.R.G., 2011. Estudo da influência do uso e ocupação de solo na qualidade da água de dois córregos da Bacia hidrográfica do rio Pirapó. Acta Scientiarum Technology 33, 295303.

Smith, V.H., Schindler, D.W., 2009. Eutrophication science: where do we go from here? Trends in Ecology \& Evolution 24, 201-207.

Thornton, J.A., Rast, W., 1993. A test of hypotheses relating to the comparative limnology and assessment of eutrophication in semi-arid manmade lakes. Comparative Reservoir Limnology and Water Quality Management 1-24.

USGS. United States Geological Survey, 2017. Earh Explorer. Available: https://earthexplorer.usgs.gov/. 
Acess: 12 mar. 2017.

Vidal, T.F., Capelo Neto, J., 2014. Dinâmica de nitrogênio e fósforo em reservatório na região semiárida utilizando balanço de massa. Revista Brasileira de Engenharia Agrícola e Ambiental 14, 402-407. 